\title{
WHAT IS THE "POSTMODERN" AGENDA? AN INTRODUCTION
}

\author{
by ELLEN MEIKSINS WOOD
}

Historic Change Without History?

During the First World War, Oswald Spengler wrote his famous and distasteful book, The Decline of the West, proclaiming that Western civilization and its dominant values were coming to an end. The bonds and traditions that had held society together were decomposing, the solidarities of life disintegrating, together with the unity of thought and culture. Like every other civilization which had gone through its natural cycle, he argued, the West had inevitably passed from its autumn of (an already destructive) "illumination" or "enlightenment" to a winter of individualism and cultural nihilism.

About four decades later, C. Wright Mills announced that "We are at the ending of what is called The Modern Age." This age "is being succeeded by a postmodern period," in which all the historic expectations that have characterized "Western culture" are no longer relevant. The Enlightenment faith in the united progress of reason and freedom, together with the two principal ideologies grounded in that faith-liberalism and socialism-"have virtually collapsed as adequate explanations of the world and of ourselves." J.S. Mill and Karl Marx were equally outdated. ${ }^{1}$

Ellen Meiksins Wood's latest book is Democracy Against Capitalism: Renewing Historical Materialism (Cambridge, 1995). 
Between these two announcements of epochal decline, one published in 1918, the other in 1959, there are, of course, great ideological differences-the antidemocratic sentiments of Spengler as against the radicalism of Mills, Spengler's hostility (or at least ambivalence) toward the Enlightenment as against Mills' continuing, if somewhat hopeless, adherence to Enlightenment values. But there is also a catastrophic intervening history of depression, war, and genocide, followed by the promise of material prosperity, the one exceeding humanity's worst fears to date, the other its most visionary hopes. When Spengler wrote The Decline of the West, Europe was certainly in turmoil, in a time of war and revolution, not to mention the apparent threat to ruling classes, even in non revolutionary situations, coming from the spread of mass democracy. Mills' vantage point was rather different. Since 1918 , the world had passed through horrors far greater than Spengler could have imagined; but Mills was writing in the quiet $1950 \mathrm{~s}$, on a rising tide of capitalist prosperity (the "affluent society"), in a climate of political apathy. And he was teaching a generation of university students who, though living in the shadow of the Cold War and the nuclear threat, enjoyed uniquely bright material prospects. In fact, this "Golden Age" of capitalism (as Eric Hobsbawm has called it ${ }^{2}$ ) was just then convincing other academics of Mills' generation (most of them apparently blind to what Michael Harrington called "the other America," not to mention U.S. imperialism) that the problems of Western society had been more or less solved, that the conditions of social harmony were more or less in place, that, in fact, the realization of Enlightenment progress was close enough if not complete, or at the very least that nothing much better was likely, necessary, or even desirable. This is what Mills' colleague Daniel Bell (who, in a later edition of his famous book, was to attack Mills viciously as a traitor over Cuba) called the "end of ideology."

So the death of Enlightenment optimism was not, for Mills, the outcome of some unambiguous catastrophe. On the contrary, his pessimism was born of success as much as failure. 
Many of the Enlightenment's principal objectives, he suggested, had indeed been realized: the "rationalization" of social and political organization; scientific and technological progress that would have been inconceivable to the most optimistic Enlightenment dreamer; the spread of universal education in advanced Western societies; and so on. Yet these advances had done little to increase the "substantive rationality" of human beings; and, if anything, "rationalization," bureaucracy, and modern technology had restricted rather than enhanced human freedom. They had even been the source of many unexpected evils. The frightening consequence of this lack of correspondence between "rationality" and freedom had been the advent of alienated human beings, or "cheerful robots," who adapted themselves to conditions-giant organizations and overpowering forcesover which they had, and felt they had, no control, people who could no longer be assumed to have an urge for freedom or a will to reason.

Some of these themes had long been a part of Western social theory-in the sociology of Max Weber or Karl Mannheim, for instance, not to mention Marxist theories of alienation. And ambivalence toward the Enlightenment, together with pessimism about progress, has been a common theme of twentieth-century culture, on the left and the right, for both good and bad reasons. But in Mills' day, there was another dimension, and this too had less to do with failure than success: the flourishing of "welfare" and "consumer" capitalism. In fact, this became a major determining factor in the development of left social theory. Many social critics on the left-Marcuse is a prime example-felt sure that this new kind of capitalism had cast an irrevocable spell on the "masses," and the working class in particular. Mills, who urged the left to abandon the "labor metaphysic," was certainly not alone in thinking that the working class was no longer available as an oppositional force. There were even people who thought of themselves as Marxists yet shared something like this view; and this was to become a dominant theme in the "revolutions" of the sixties, in student radicalism, and in forms of Marxist 
theory that gave an increasing prominence to students and intellectuals as the main agents of resistance and "cultural revolution."

Today, while some on the right have proclaimed the "end of history" or the final triumph of capitalism, we are being told yet again by some left intellectuals that an epoch has ended, that we are living in a "postmodern" age, that the "Enlightenment project" is dead, that all the old verities and ideologies have lost their relevance, that old principles of rationality no longer apply, and so on. This time, at least for many academics and university students, it seems that the real watershed occurred some time in the late 1960s, or maybe even in 1989, with the collapse of the Berlin Wall. Yet, though much historical water has passed under the bridge between the early epochal milestones and the most recent ones, what is striking about the current diagnosis of postmodernity is that it has so much in common with older pronouncements of death, both radical and reactionary versions. What has ended, apparently, is not so much another, different epoch but the same one all over again.

But the other thing worth noting is that the most recent analyses of postmodernity, which combine so many features of older diagnoses of epochal decline, are remarkably unconscious of their own history. In their conviction that what they say represents a radical rupture with the past, they are sublimely oblivious to everything that has been said so many times before. Even the epistemological skepticism, the assault on universal truths and values, the questioning of self-identity, which are so much a part of the current intellectual fashions have a history as old as philosophy. More particularly, the postmodern sense of epochal novelty depends on ignoring, or denying, one overwhelming historical reality: that all the ruptures of the twentieth century have been bound together in a single historical unity by the logic-and the internal contradictions-of capitalism, the system that dies a thousand deaths. 
This brings us to the most distinctive characteristic of the new postmodernists: despite their insistence on epochal differences and specificities, despite their claim to have exposed the historicity of all values and "knowledges" (or precisely because of their insistence on "difference" and the fragmented nature of reality and human knowledge), they are remarkably insensitive to history. This insensitivity is revealed not least in a deafness to the reactionary echoes of their attacks on "Enlightenment" values and their fundamental irrationalism. Here, then, is one major difference between the current enunciations of epochal change and all the others. Earlier theories were based-by definition-on some particular conception of history, and were predicated on the importance of historical analysis. C. Wright Mills, for example, insisted that the crisis of reason and freedom which marked the onset of the postmodern age represented

structural problems, and to state them requires that we work in the classic terms of human biography and epochal history. Only in such terms can the connections of structure and milieux that affect these values today be traced and causal analysis be conducted.

Mills also took it for granted, in classic Enlightenment fashion, that the whole point of such historical analysis was to mark out the space of human freedom and agency, to formulate our choices and "enlarge the scope of human decisions in the making of history." And for all his pessimism, he assumed that the limits of historical possibility were, in his time, "very broad indeed."

This statement is in nearly every particular antithetical to the current theories of postmodernity, which effectively deny the very existence of structure or structural connections and the very possibility of "causal analysis." Structures and causes have been replaced by fragments and contingencies. There is no such thing as a social system (e.g., the capitalist system) with its own systemic unity and "laws of motion." There are only many different kinds of power, oppression, identity, and "discourse." Not only do we have to reject the old "grand narratives," like Enlightenment concepts of progress, 
we have to give up any idea of intelligible historical process and causality, and with it, evidently, any idea of "making history." There are no structured processes accessible to human knowledge (or, it must be supposed, to human action). There are only anarchic, disconnected, and inexplicable differences. For the first time, we have what appears to be a contradiction in terms: a theory of epochal change based on a denial of history.

There is one other especially curious thing about the new idea of postmodernity, one particularly notable paradox. On the one hand, the denial of history on which it is based is associated with a kind of political pessimism. Since there are no systems and no history susceptible to causal analysis, we cannot get to the root of the many powers that oppress us; and we certainly cannot aspire to some kind of united opposition, some kind of general human emancipation, or even a general contestation of capitalism, of the kind that socialists used to believe in. The most we can hope for is a lot of particular and separate resistances. On the other hand, this political pessimism appears to have its origins in a rather optimistic view of capitalist prosperity and possibility. Today's postmodernists (typically survivors of the "sixties generation" and their students) seem to have a view of the world still rooted in the "Golden Age" of capitalism, the dominant feature of which is "consumerism," the multiplicity of consumption patterns, and the proliferation of "life-styles." Here too they reveal their fundamental ahistoricism, as the structural crises of capitalism since that "golden" moment seem to have passed them right by, or at least to have made no significant theoretical impression. For some, this means that the opportunities for opposition to capitalism are severely limited. Others seem to be saying that, if we can't really change or even understand the system (or even think about it as a system at all), and if we don't, and can't, have a vantage point from which to criticize the system, let alone oppose it, we may as well lie back and enjoy it. Exponents of these intellectual trends certainly know that all is not well; but there is very little in these fashions that helps, 
for example, to make sense of today's increasing poverty and homelessness, the growing class of working poor, new forms of insecure and part-time labor, and so on. Both sides of the twentieth-century's ambiguous history-both its horrors and its wonders-have no doubt played a part in forming the postmodernist consciousness; but the horrors that have undermined the old idea of progress are less important in defining the distinctive nature of today's postmodernism than are the wonders of modern technology and the riches of consumer capitalism. Postmodernism sometimes looks like the ambiguities of capitalism as seen from the vantage point of those who enjoy its benefits more than they suffer its costs.

If for Mills it was the central problem of his age that cheerful robots could no longer be relied on to possess an urge for freedom or a will to reason, the new postmodernists regard those threatened Enlightenment values themselves as the problem and have openly rejected them as intrinsically oppressive. Maybe in its defeatist submission to apparently uncontrollable forces, combined with a surrender to, and sometimes even a celebration of, consumerism, the postmodernist current actually represents an intellectual manifestation of those robotsonly where Mills seems to have held the rather elitist view that workers were more likely to be robots, leaving it for students and intellectuals to rise above the robotic condition, now it is those very intellectuals who have become, so to speak, the cheerful robot's theoretical consciousness.

Cheerful Robots or Socialist Critics?

It would be easy after having said all this to dismiss the current fashions. But for all their contradictions, their lack of historical sensitivity, their apparently unconscious repetition of old themes, and their defeatism, they are also responding to something real, to real conditions in the contemporary world in the current conditions of capitalism, with which people on the socialist left must come to terms. 
Here, first, is a list of the most important themes of the "postmodern" left (I shall use that term broadly to cover a variety of intellectual and political trends that have emerged in recent years, including "post-Marxism" and "poststructuralism"): a focus on language, culture, and "discourse" (on the grounds that language is all we can know about the world and we have access to no other reality), to the exclusion of the left's traditional "economistic" concerns and the old preoccupations of political economy; a rejection of "totalizing" knowledge and of "universalistic" values (including Western conceptions of "rationality," general ideas of equality, whether liberal or socialist, and the Marxist conception of general human emancipation), in favor of an emphasis on "difference," on varied particular identities such as gender, race, ethnicity, sexuality, on various particular and separate oppressions and struggles; an insistence on the fluid and fragmented nature of the human self (the "decentered subject"), which makes our identities so variable, uncertain, and fragile that it is hard to see how we can develop the kind of consciousness that might form the basis of solidarity and collective action founded on a common social "identity" (such as class), a common experience, and common interests-a celebration of the "marginal"; and a repudiation of "grand narratives," such as Western ideas of progress, including Marxist theories of history. All of these themes tend to be lumped together in a dismissal of "essentialism," in particular Marxism, which allegedly reduces the varied complexity of human experience to a monolithic view of the world, "privileging" the mode of production as a historical determinant and class as against other "identities," and "economic" or "material" determinants as against the "discursive construction" of reality. This denunciation of "essentialism" tends to cover not just truly monolithic and simplistic explanations of the world (like Stalinist varieties of Marxism) but any kind of causal analysis.

The meaning of this postmodernist jargon should become clearer in the course of the articles that follow here; but for the moment, it should be obvious that the main thread 
running through all these postmodern principles is an emphasis on the fragmented nature of the world and of human knowledge, and the impossibility of any emancipatory politics based on some kind of "totalizing" vision. Even an anticapitalist politics is too "totalizing" or "universalist," since capitalism as a totalizing system can hardly be said to exist at all in postmodern discourse, so that even the critique of capitalism is precluded. In fact, "politics" in any traditional sense of the word, having to do with the overarching power of classes or states and opposition to them, is effectively ruled out, giving way to the fractured struggles of "identity politics" or even the "personal as political"-though there are some more universal projects that do hold some attractions for the postmodern left, such as environmental politics. In short: a deep epistemological skepticism and a profound political defeatism.

Yet none of us would want to deny the importance of some of these themes. For instance, the history of the twentieth century could hardly inspire confidence in traditional notions of progress, and those of us who profess to believe in some kind of "progressive" politics have to come to terms with all that has happened to undermine Enlightenment optimism. And who would want to deny the importance of "identities" other than class, of struggles against sexual and racial oppression, or the complexities of human experience in such a mobile and changeable world, with such fragile and shifting solidarities? At the same time, who can be oblivious to the resurgence of "identities" like nationalism as powerful, and often destructive, historical forces? Don't we have to come to terms with the restructuring of capitalism, now both more global and more "segmented" than ever before? For that matter, who is unaware of the structural changes that have transformed the nature of the working class itself? And what serious socialist has ever been unconscious of the racial or sexual divisions within the working class? Who would want to subscribe to the kind of ideological and cultural imperialism that suppresses the multiplicity of human values and cultures? And how can we possibly deny the importance of language 
and cultural politics in a world so dominated by symbols, images, and "mass communication," not to mention the "information superhighway?" Who would deny these things in a world of global capitalism so dependent on the manipulation of symbols and images in a culture of advertisement, where the "media" mediate our own most personal experiences, sometimes to the point where what we see on television seems more real than our own lives, and where the terms of political debate are set-and narrowly constricted-by the dictates of capital in the most direct way, as knowledge and communication are increasingly in the hands of corporate giants?

We don't have to accept postmodernist assumptions in order to see all these things. On the contrary, these developments cry out for a materialist explanation. For that matter, there have been few cultural phenomena in human history whose material foundations are more glaringly obvious than those of postmodernism itself. There is, in fact, no better confirmation of historical materialism than the connection between postmodernist culture and a segmented, consumerist, and mobile global capitalism. Nor does a materialist approach mean that we have to devalue or denigrate the cultural dimensions of human experience. A materialist understanding is, instead, an essential step in liberating culture from the stranglehold of commodification.

If postmodernism does tell us something, in a distorted way, about the conditions of contemporary capitalism, the real trick is to figure out exactly what those conditions are, why they are, and where we go from here. The trick, in other words, is to suggest historical explanations for those conditions instead of just submitting to them and indulging in ideological adaptations. The trick is to identify the real problems to which the current intellectual fashions offer false-or no-solutions, and in so doing to challenge the limits they impose on action and resistance. The trick, therefore, is to respond to the conditions of the world today not as cheerful (or even miserable) robots, but as critics. 
This special issue of Monthly Review is intended to suggest some of the ways in which historical materialism can shed light on these matters, though obviously, in such a small space, we can only scratch the surface. In organizing this issue, John Foster and I sent a letter to potential contributors explaining what we had in mind, so let me conclude this introduction with some extracts from that letter. It starts with a quotation from my article in last year's summer issue, dealing with the work of E.P. Thompson:

The critique of capitalism is out of fashion-and here there is a curious convergence, a kind of unholy alliance, between capitalist triumphalism and socialist pessimism. The triumph of the right is mirrored on the left by a sharp contraction of socialist aspirations. Left intellectuals, if they are not actually embracing capitalism as the best of all possible worlds, have little hope for anything more than a bit more space within the interstices of capitalism; and they look forward, at best, to only the most local and particular resistances. And there is another curious effect of all this. Capitalism is becoming so universal, so much taken for granted, that it is becoming invisible.

Now clearly we have plenty to be pessimistic about. Recent and current events have given us plenty of cause. But there is something curious about the way many of us are reacting to all this. If capitalism has indeed triumphed, you might think that what we need now more than ever is a critique of capitalism. Why is this the right moment to embrace modes of thought which seem to deny the very possibility not only of surpassing capitalism but even of critically understanding it?...

I really do think we are in an unprecedented situation now, something we have not seen in the whole history of capitalism. What we are experiencing now is not just a deficit of action, or the absence of the necessary instrumentalities and organization of struggle (though those are certainly thin on the ground). It is not only that we do not know how to act against capitalism but that we are forgetting even how to think against it.

\section{Our letter than went on to spell out our intentions:}

This is the context in which we are planning the special issue. We start from the premise that historical work like E.P. Thompson's, and Marxist political economy at its best, are essential to the left's critical project.... The point, though, is this: we can't now take it for granted that other left intellectuals share our view; and, speaking as teachers, we are both all too conscious that many, if not most, of our studentseven those who think of themselves as on the left-are unlikely to agree, either about our understanding of capitalism or about our epistemological and historical presuppositions. And these disagreements are 
expressed in a very different intellectual, not to mention political, agenda....

What we are proposing, then, is a collection of articles that will offer some suggestions about how historical materialism can deal with that other agenda in more fruitful, forceful, and liberating ways than the current intellectual and political fashions are able to do.

We are not suggesting that people like us should abandon our own terrain. On the contrary, part of the object is to demonstrate that our terrain is where it's at-for example, that the old bread-and-butter issues of the left (like "politics" in the old sense, having to do with state and class power) are still at the center of things, and still important to other emancipatory projects, not just to traditional forms of class politics. But we can grab the attention of our students and other people like them if we confront them on their own favorite turf.

This, then, is what we have set out to do, in a very limited way. The themes of this issue, and often the style, may be different from what $M R$ readers are used to, but the fundamental motivation and political commitment remain the same. Our main message is that this may be just the right time to revitalize a Marxist critique. The world is increasingly populated not by cheerful robots but by some very angry human beings. As things stand, there are very few intellectual resources available to understand that anger, and hardly any political ones (at least on the left) to organize it. Today's postmodernism, for all its apparently defeatist pessimism, is still rooted in the Golden Age of capitalism. It's time to leave that legacy behind and face the realities of the 1990 s and the twenty-first century.

\section{NOTES}

1. C. Wright Mills, The Sociological Imagination (Oxford and New York, 1959), pp. 165-67.

2. In Hobsbawm's Age of Extremes: The Short Twentieth Century, 1914-1991 (London, 1994); U.S. edition The Age of Extremes: A History of the World, 1914-1991 (New York: Pantheon, 1995), the "golden age" (roughly 1947-1973) is sandwiched between the "age of catastrophe" and "the landslide."

3. I discuss some of these developments in "A Chronology of the New Left, or: Who's Old-Fashioned Now"?, Socialist Register 1995 (New York and London, 1995).

4. Mills, The Sociological Imagination, pp. 1734. 